\title{
Locally Advanced Unresectable Carcinoma
}

National Cancer Institute

\section{Source}

National Cancer Institute. Locally Advanced Unresectable Carcinoma. NCI Thesaurus.

Code C155698.

A carcinoma that has spread from its original site of growth to nearby tissues or lymph nodes and is not amenable to surgical resection. 